\title{
EFFECT OF POPULATION DENSITIES OF Heterodera glycines RACE 3 ON LEAF AREA, PHOTOSYNTHESIS AND YIELD OF SOYBEAN
}

\author{
GUILHERME L. ASMUS ${ }^{1 *}$ \& LUIZ CARLOS C. B. FERRAZ ${ }^{2 *}$
}

${ }^{1}$ EMBRAPA, Centro de Pesquisa Agropecuária do Oeste, Cx. Postal 661, 79804-970, Dourados, MS, e-mail: asmus@cpao.embrapa.br; ${ }^{2}$ ESALQ/USP, Departamento de Entomologia, Fitopatologia e Zoologia Agrícola,

Cx. Postal 9, 13418-900, Piracicaba, SP

(Accepted for publication on 15/03/2002)

Corresponding author: Guilherme L. Asmus

ASMUS, G.L. \& FERRAZ, L.C.C.B. Effect of population densities of Heterodera glycines race 3 on leaf area, photosynthesis and yield of soybean. Fitopatologia Brasileira 27:273-278. 2002.

\begin{abstract}
The effect of Heterodera glycines on photosynthesis, leaf area and yield of soybean (Glycine max) was studied in two experiments carried out under greenhouse condition. Soybean seeds were sown in 1.51 (Experiment 1) or 5.01 (Experiment 2) clay pots filled with a mixture of field soil + sand (1:1) sterilized with methyl bromide. Eight days after sowing, seedlings were thinned to one per pot, and one day later inoculated with $0 ; 1.200 ; 3.600 ; 10.800$; 32.400 or $97.200 \mathrm{~J}_{2}$ juveniles of $H$. glycines. Experiment 1 was carried out during the first 45 days of the inoculation while Experiment 2 was conducted during the whole cycle of the crop. Measurements of photosynthetic rate, stomatic conductance, chlorophyll fluorescence, leaf color, leaf area, and chlorophyll leaf content were taken at ten-day intervals throughout the experiments.

Data on fresh root weight, top dry weight, grain yield, number of eggs/gram of roots, and nematode reproduction factor were obtained at the end of the trials. Each treatment was replicated ten times. There was a marked reduction in both photosynthetic rate and chlorophyll content, as well as an evident yellowing of the leaves of the infected plants. Even at the lowest Pi, the effects of $H$. glycines on the top dry weight or grain yield were quite severe. Despite the parasitism, soybean yield was highly correlated with the integrated leaf area and, accordingly, the use of this parameter was suggested for the design of potential damage prediction models that include physiological aspects of nematode-diseased plants.

Additional keywords: crop loss, Glycine max, Heterodera glycines, soybean cyst nematode.

\section{RESUMO}

Efeito de níveis populacionais de Heterodera glycines raça 3 sobre a área foliar, fotossíntese e produção de soja

Os efeitos do parasitismo de Heterodera glycines sobre a fotossíntese, a área foliar e a produção da soja (Glycine Max) foram estudados em casa de vegetação. Dois experimentos foram realizados: Experimento 1, em recipientes menores, até 45 dias após as inoculações e Experimento 2, em recipientes maiores, até o final do ciclo vegetativo da soja . Plantas com nove dias da germinação foram individualmente inoculadas com $0,1.200,3.600,10.800,32.400$ ou 97.200 juvenis $\mathrm{J}_{2}(=\mathrm{Pi})$. A cada dez dias após a inoculação, foram tomadas medidas da taxa fotossintética, condutância estomática, fluorescência da clorofila $a$, cor das folhas, teor de clorofila e área foliar. Ao final dos experimentos, foram determinadas a massa fresca do sistema radicular, massa seca total da parte aérea, produção

de grãos (Experimento 2) e taxa reprodutiva dos nematóides. Nos dois experimentos, os tratamentos foram dispostos em blocos ao acaso, com dez repetições. Ocorreram marcantes reduções da taxa fotossintética e do teor de clorofila foliar e observou-se intenso amarelecimento das folhas. Mesmo na menor densidade populacional (1.200), o nematóide causou expressivas reduções na área foliar, na massa fresca das raízes e na produção de massa seca total da parte aérea e de grãos. A produção da soja parasitada por $H$. glycines apresentou alta correlação com a integral da área foliar, podendo-se cogitar do uso dessa variável na elaboração de modelos de previsão de danos que levem em consideração a fisiologia de produção de plantas infectadas por nematóides.
\end{abstract}

\section{INTRODUCTION}

The soybean cyst nematode (SCN), Heterodera glycines Ichinohe, is a major problem in soybean [Glycine $\max$ (L.) Merril] all over the world (Wrather et al., 1997). Since 1992, when it was first detected in the states of Goiás, Mato Grosso, Mato Grosso do Sul and Minas Gerais, in Brazil, the infested area has increased to 1.7 million hectares, while

$\overline{* \mathrm{CNPq}}$ fellowship accumulated losses have reached an estimated US $\$ 200$ million (Yorinori, 2000). Fourteen races have already been found but race 3 is the most widespread over the infected soybean growing areas (Dias et al., 1999).

Above-ground symptoms exhibited by sedentary endoparasitic nematode-infected plants, such as stunting, yellowing, and wilting, usually are due to the induction of specialized nurse cells, which cause disruption of the root vascular system, reducing water and nutrient uptake and transport from roots to shoots. In other words, plant responses 
to parasitism are related to physiological changes that affect the photosynthetic process (Hussey \& Williamson, 1998). Crop losses due to SCN have been closely related to its population density at planting time $(=\mathrm{Pi})$. Nevertheless, only a few studies have been done dealing with the effects of $H$. glycines parasitism on the physiology of soybean plants, including photosynthesis and related processes (Postuka et al., 1986; Koenning \& Barker, 1995; Melakeberhan, 1999), as well as on their impact on final yield, a feature that possibly could be used for establishing prediction models of crop losses.

Therefore, the objective of this work was to study the relationships between initial population densities of $H$. glycines race 3, leaf area, photosynthesis, and yield of soybean.

\section{MATERIAL AND METHODS}

Two greenhouse experiments (Experiments 1 and 2) were carried out using soybean 'Embrapa 133', rated as susceptible to $H$. glycines race 3 . The temperature ranged between 12 and $32^{\circ} \mathrm{C}$, av. $28^{\circ} \mathrm{C}$. In Experiment 1, data were collected 45 days after plant inoculation whereas in Experiment 2 the plants developed to harvest (110 days after sowing). This procedure was intended to evaluate the extension of the damage caused during the initial 45-day period of plant growth, which would allow the nematode to complete only one generation, and to compare it with the depressive effects due to parasitism occurring at the normal harvest time (three to four generations). It was also expected that any recovery of the infected plants during their growth cycle could be detected.

\section{Experiment 1}

Soybean seeds inoculated with Bradyrhizobium japonicum Buchanan (Bioagro 10®; 80,000 cells/seed) were sown in 1.51 clay pots filled with a substrate $(78 \%$ sand, $6 \%$ silt, and $16 \%$ clay) sterilized with methyl bromide $(150 \mathrm{ml} /$ $\mathrm{m} 3)$. Eight days later, seedlings were thinned to one per pot, and one day later inoculated with $0 ; 1.200 ; 3.600 ; 10.800$; 32.400 or $97.200 \mathrm{~J}_{2}$ juveniles of $H$. glycines (= Pis). Inoculum was obtained by crushing mature females on a $150 \mu \mathrm{m}$ sieve for releasing the eggs that were put in a hatching chamber during three days in tap water at $27{ }^{\circ} \mathrm{C}$, followed by an additional period of seven to ten days at $25{ }^{\circ} \mathrm{C}$ in a $0,01 \mathrm{M}$ $\mathrm{ZnSO}_{4} \cdot 7 \mathrm{H}_{2} \mathrm{O}$ solution. One week later, plants were additionally fertilized with $1.0 \mathrm{~g}$ of a NPK formula $0-30-15$ per pot. At a ten-day interval schedule, the following evaluations were done: a) Leaf area: obtained by the equation $\mathrm{LA}=0,0139 \times \mathrm{L}^{2,0091}$, where LA is the leaf area $\left(\mathrm{cm}^{2}\right)$ and L is the length $(\mathrm{mm})$ of the central leaflet. At each evaluation, the length of the central leaflet of all leaves of every plant was measured, and at the end of the experiment the total leaf area was integrated (= leaf area duration, LAD) according to the following equation (Hunt, 1978): $\mathrm{LAD}=\sum\left[\left(\mathrm{LA}_{\mathrm{tx}}+\mathrm{LA}_{\mathrm{tx}+1}\right)\right.$ /2 ] $\left(\mathrm{t}_{\mathrm{x}+1}-\mathrm{t}_{\mathrm{x}}\right)$, where LAD = integrated leaf area $\left(\mathrm{cm}^{2}\right)$, and $\mathrm{LA}_{\mathrm{tx}}=$ leaf area of a specific plant at a specific day after inoculation $\left(\mathrm{t}_{\mathrm{x}}\right)$; b) Photosynthetic rate and stomatic conductance: evaluated with a LI-6400 Portable Photosynthesis System (Li-Cor $\left.{ }^{\circledR}\right)$. Measurements were taken at $1,000 \mu \mathrm{mol} \mathrm{m} \mathrm{m}^{-2} \mathrm{~s}^{-1}$ light intensity, previously defined as being the light saturation under greenhouse conditions;

c) Chlorophyll fluorescence: minimal fluorescence $\left(\mathrm{F}_{\mathrm{o}}\right)$, maximal fluorescence $\left(\mathrm{F}_{\mathrm{m}}\right)$, and optimal quantum $\left(\mathrm{F}_{\mathrm{v}} / \mathrm{F}_{\mathrm{m}}\right)$ yield of photosystem II (PSII) were evaluated with a Portable Fluorometer PAM-2000 (Walz, Germany);

d) Leaf color: determined using a Color Reader CR-10 (Minolta). The CR-10 expresses color numerically in the $L * a * b$ color space, also referred to as CIELAB, where $\mathrm{L}$ indicates lightness, and $a$ and $b$ are chromaticity coordinates that represent the red-green and the yellowblue direction, respectively. The color difference $(\Delta \mathrm{Eab})$ between any specific leaf and the average color of the noninoculated controls was calculated by using the equation:

$$
\Delta \mathrm{Eab}=\sqrt{(\Delta L)^{2}+(\Delta a)^{2}+(\Delta b)^{2}}
$$

where $\Delta L, \Delta a$, and $\Delta b$ are the differences in $L, a$, and $b$ values between leaf color and average color of the control leaves (Lopes, 1999).

Except for the measurement of the leaf area, the central leaflet of the upper expanded trifoliate leaf was used in all evaluations. Data on fresh root weight, top dry weight, number of eggs per gram of roots, and reproduction factor $(\mathrm{RF}=\mathrm{Pf} /$ $\mathrm{Pi}$; Pf = total number of eggs extracted from roots) were obtained at the end of the trial. A statistical design was used consisting of randomized blocks with six treatments corresponding to the inoculum levels (Pis) previously mentioned and ten replicates. The experimental unit consisted of one plant per pot.

\section{Experiment 2}

The same methodology described for Experiment 1 was used in Experiment 2, with the following alterations or additions: i) 5 1-clay pots were used to allow the plants to develop to harvest; ii) due to differences reported in leaf color, the leaf chlorophyll content was determined $\left(\mathrm{ng} / \mathrm{cm}^{2}\right)$ by using a SPAD-502 chlorophyll meter (Minolta Co., Ltd.); and iii) data on plant yield (dry weight of grains) was also collected.

\section{RESULTS AND DISCUSSION}

Due to the similarity of the results obtained, only data regarding the Experiment 2 are presented and discussed. Nevertheless, the nematode reproductive data in both trials have been included.

\section{Effects of initial population densities on the nematode reproduction}

Reproduction of $H$. glycines (Table 1) followed the normal pattern for nematode population build up as a function of Pi (McSorley, 1998), i.e., at low Pis there was an exponential increase in the number of nematodes during a 
short period followed by a progressive reduction of growth rate probably due to competition for food. This basic trend was observed in relation to the reproductive features in both Experiments. In Experiment 2, at the two highest Pis, overlapping of the nematode generations associated with a stunted condition, and the necrotic and very much smaller root system of the infected plants found later in the cycle, most probably accounted for the much lower values of eggs per gram of roots and reproduction factor than those observed in Experiment 1 (Table 1).

\section{Effects of Heterodera glycines on physiological processes of soybean}

In general, $H$. glycines caused a decrease in the photosynthetic rate of leaves of the infected plants (Figure 1a). Such reduction had already been reported (Postuka et al., 1986; Koenning \& Barker, 1995), its extent depending on soybean variety, soil type, availability of nutrients and experimental conditions (greenhouse or field).

Among the physiological processes that have often been considered responsible for the reduction of the photosynthetic activity in nematode-infected plants are: decreased chlorophyll content (Nagesh \& Dhawan, 1988), changes in stomatic conductance (Saeed et al., 1997), photochemical limitations (Schans \& Arntzen, 1991), nutrient unbalance (Wallace, 1974) and interference on the synthesis and translocation of photosynthesis regulating factors produced in the roots (Loveys \& Bird, 1973). In the interaction of $H$. glycines and susceptible soybean varieties, reduced photosynthetic activity has been primarily related to a lesser amount of nutrients, particularly nitrogen, either absorbed or translocated by the infected roots (Koenning \& Barker, 1995), a feature that can occur in association with the suppression of nodulation of nitrogen-fixing-bacteria (Ko et al., 1984). Due to their natural resistance to inner water movement, soybean plants demand high water availability (Shibles et $a l .$, 1975). Despite this, there was no interference of $H$. glycines on stomatic activity (Figure 1b). These results agree

TABLE 1 - Number of eggs per gram of roots and reproduction factor (RF) of Heterodera glycines on susceptible 'Embrapa 133' soybean (Glycine max) plants at 45 and 101 days after inoculation (DAI) with increasing population densities $(\mathrm{Pi})$

\begin{tabular}{|c|c|c|c|c|c|c|}
\hline & \multicolumn{6}{|c|}{ Pi $\left(\mathrm{J}_{2} / \text { plant }\right)^{*}$} \\
\hline & $\mathbf{0}$ & 1.200 & 3.600 & 10.800 & 32.400 & 97.200 \\
\hline & \multicolumn{6}{|c|}{45 DAI (Experiment 1) } \\
\hline Eggs/g & $0,0 \mathrm{a}$ & $4.371 \mathrm{~b}$ & $8.820 \mathrm{~b}$ & $36.051 \mathrm{c}$ & $82.736 \mathrm{~d}$ & $79.568 \mathrm{~d}$ \\
\hline \multirow[t]{2}{*}{$\mathrm{RF}$} & $0,0 \mathrm{a}$ & $37,2 \mathrm{~d}$ & $21,1 \mathrm{c}$ & $24,5 \mathrm{~cd}$ & $12,0 \mathrm{bc}$ & $3,3 a b$ \\
\hline & \multicolumn{6}{|c|}{101 DAI (Experiment 2) } \\
\hline Eggs/g & $0,0 \mathrm{a}$ & $25.143 \mathrm{~b}$ & $33.144 \mathrm{~b}$ & $33.009 \mathrm{~b}$ & $28.640 \mathrm{~b}$ & $26.748 \mathrm{~b}$ \\
\hline $\mathrm{RF}$ & $0,0 \mathrm{a}$ & $400,3 \mathrm{~d}$ & $114,8 \mathrm{c}$ & $28,1 \mathrm{~b}$ & $5,4 \mathrm{a}$ & $1,8 \mathrm{a}$ \\
\hline
\end{tabular}

with those found for other plant-nematode interactions, such as Meloidogyne incognita (Kofoid \& White) Chitwood on vine (Vitis vinifera L.) varieties (Melakeberhan et al., 1990) and Globodera pallida (Stone) Behrens on potato (Solanum tuberosum L.) varieties (Schans \& Arntzen, 1991). On the other hand, Bird (1974) hypothesized that the reduced photosynthetic rate could be related to partial closure of the stomata caused by water stress due to the nematode-damaged roots, resulting in decreased $\mathrm{CO}_{2}$ entrance in the leaves and, as a consequence, a reduced rate of assimilation.

No changes were noticed in the emission of chlorophyll fluorescence (Figure 1c), suggesting that the SCN does not interfere with the electron transport system in PSII. The low Pearson's correlation coefficient (Table 2) reinforces the idea that the observed variation in photosynthetic rate was not due to any change in the transport of electrons in PSII.

Most of the observed changes $(\Delta \mathrm{Eab})$ in the leaf color of infected plants (Figure 1d) referred to an intense yellowing, thus justifying the common name "Soybean Yellow Dwarf" used to designate the disease all over the world. The high negative correlation $(r=-0,81 ; p<0,01)$ observed between deviation of leaf color and chlorophyll content leads to the hypothesis that reduction of chlorophyll content is one of the most important factors in determining the intense yellowing of infected plants. Our results show that there was a clear reduction in chlorophyll content following the increase of $\mathrm{Pi}$ (Figure 1e). In several other plant-nematode interactions (Nagesh \& Dhawan, 1988), the effect of nematode parasitism on chlorophyll content was also reported and related to reduced photosynthetic activity in infected plants. In relation to soybeans, Ma et al. (1995) found a high correlation between leaf color (based upon the chlorophyll content) and photosynthetic rate. Differences in nematode-infected soybean leaf color can actually result from reduction of the chlorophyll content. However, the correlation coefficients between photosynthetic rate and leaf color deviation or chlorophyll content determined in our experiments (Table 2) do not explain all variation in photosynthetic rate. In this case, a better explanation is possibly provided by the fact that the chlorophyll content in soybean leaves usually exceeds the amount needed for a normal photosynthetic activity (Müller, 1981) and, accordingly, a slight chlorosis does not correspond to a noticeable effect on photosynthetic rate. Even at low chlorophyll content soybean leaves are capable of maintaining the photosynthetic activity through a compensatory mechanism that goes toward an increase of the electron transport and phosphorilation rate (Brun, 1978). The leaf color deviation observed can also be explained by lack of nitrogen due to the fewer nodules of symbiotic bacteria in roots infected by SCN (Ko et al., 1984). The decrease in root nodulation has also been considered one of the causes for the reduction of photosynthetic rate in infected soybean plants (Postuka et al., 1986; Koenning \& Barker, 1995; Melakeberhan, 1999).

The complex relationships between SCN initial population densities and soybean photosynthetic activity reported in the present study and in some other related papers 

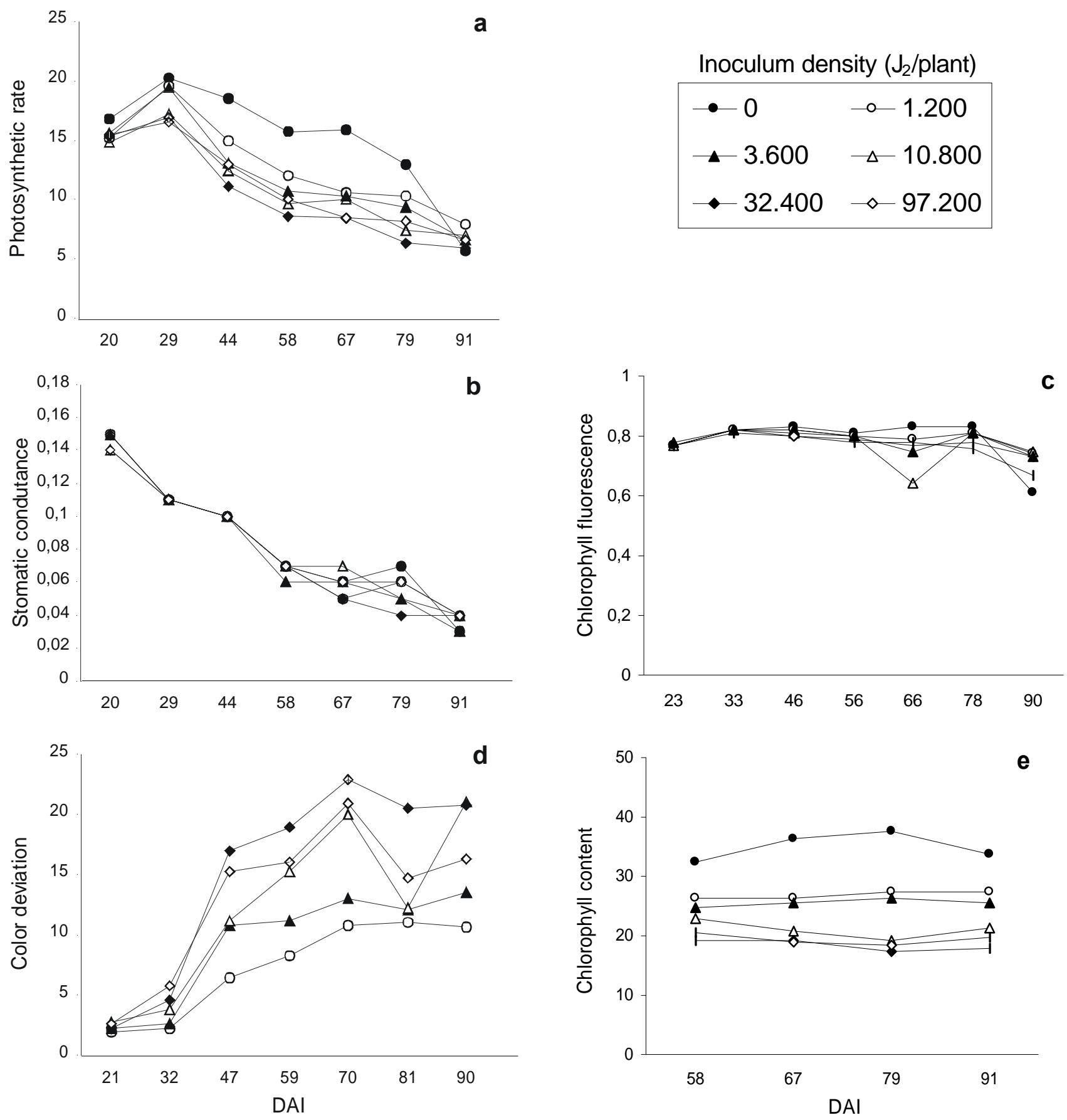

FIG. 1 - Photosynthetic rate (a), stomatic conductance (b), chlorophyll fluorescence (c), deviation of normal color (d), and chlorophyll content (e) of susceptible 'Embrapa 133' soybean (Glycine max) plants at different days after inoculation (DAI) with increasing population densities of Heterodera glycines.

indicate that photosynthesis actually can be affected by several factors, including leaf chlorophyll content as one of the most relevant.

\section{Effects of Heterodera glycines on soybean growth and yield}

One of the most noticeable effects observed in the infected plants, even at the lowest Pis, was the marked reduction in leaf area (Figure $2 \mathrm{a}$ ). This had been previously observed on SCN-infected soybean (Postuka et al., 1986) as well as in some other plant-nematode interactions involving cyst-forming species, such as Heterodera avenae Filipjev on triticale (Triticum secalotricum Meister) (Kaushal \& Madavi, 1992).

Top and grain dry weight best correlated (Table 2) with leaf area duration (LAD). Despite the generally accepted concept that the damage due to plant-parasitic nematodes is 
Effect of population densities of Heterodera glycines race $3 \ldots$

TABLE 2 - Pearson's correlation coefficients between different evaluated variables on susceptible 'Embrapa 133' soybean (Glycine max) plants inoculated with increasing population densities of Heterodera glycines race 3

\begin{tabular}{|c|c|c|c|c|c|c|c|c|}
\hline & COND & FLUO & COLOR & CHLOR & LAD & TDW & GRAIN & ROOT \\
\hline PHOTO & $\begin{array}{l}\mathrm{r}=0,76 \\
\mathrm{p}<0,01\end{array}$ & $\begin{array}{l}\mathrm{r}=0,43 \\
\mathrm{p}<0,01\end{array}$ & $\begin{array}{c}r=-0,64 \\
p<0,01\end{array}$ & $\begin{array}{l}\mathrm{r}=0,59 \\
\mathrm{p}<0,01\end{array}$ & $\begin{array}{l}\mathrm{r}=0,32 \\
\mathrm{p}<0,01\end{array}$ & $\begin{array}{l}\mathrm{r}=0,31 \\
\mathrm{p}<0,01\end{array}$ & $\begin{array}{l}\mathrm{r}=0,29 \\
\mathrm{p}<0,01\end{array}$ & $\begin{array}{l}\mathrm{r}=0,32 \\
\mathrm{p}<0,01\end{array}$ \\
\hline COND & & $\begin{array}{l}r=0,26 \\
p<0,01\end{array}$ & $\begin{array}{c}r=-0,48 \\
p<0,01\end{array}$ & $\begin{array}{l}r=0,17 \\
p<0,01\end{array}$ & $\begin{array}{l}r=0,04 \\
p=0,20\end{array}$ & $\begin{array}{l}r=0,05 \\
p=0,17\end{array}$ & $\begin{array}{l}r=0,04 \\
p=0,20\end{array}$ & $\begin{array}{l}r=0,06 \\
p=0,11\end{array}$ \\
\hline FLUO & & & $\begin{array}{c}r=-0,17 \\
p<0,01\end{array}$ & $\begin{array}{l}r=0,20 \\
p<0,01\end{array}$ & $\begin{array}{l}r=0,09 \\
p=0,03\end{array}$ & $\begin{array}{l}r=0,07 \\
p=0,07\end{array}$ & $\begin{array}{l}r=0,06 \\
p=0,12\end{array}$ & $\begin{array}{l}r=0,10 \\
p=0,02\end{array}$ \\
\hline COLOR & & & & $\begin{array}{c}r=-0,82 \\
p<0,01\end{array}$ & $\begin{array}{c}r=-0,51 \\
p<0,01\end{array}$ & $\begin{array}{c}r=-0,51 \\
p<0,01\end{array}$ & $\begin{array}{c}r=-0,49 \\
p<0,01\end{array}$ & $\begin{array}{c}r=-0,51 \\
p<0,01\end{array}$ \\
\hline CHLOR & & & & & $\begin{array}{l}r=0,75 \\
p<0,01\end{array}$ & $\begin{array}{l}\mathrm{r}=0,73 \\
\mathrm{p}<0,01\end{array}$ & $\begin{array}{l}\mathrm{r}=0,70 \\
\mathrm{p}<0,01\end{array}$ & $\begin{array}{l}r=0,75 \\
p<0,01\end{array}$ \\
\hline LAD & & & & & & $\begin{array}{l}r=0,95 \\
p<0,01\end{array}$ & $\begin{array}{l}r=0,90 \\
p<0,01\end{array}$ & $\begin{array}{l}r=0,93 \\
p<0,01\end{array}$ \\
\hline TDW & & & & & & & $\begin{array}{l}r=0,99 \\
p<0,01\end{array}$ & $\begin{array}{l}r=0,90 \\
p<0,01\end{array}$ \\
\hline GRAIN & & & & & & & & $\begin{array}{l}r=0,85 \\
p<0,01\end{array}$ \\
\hline
\end{tabular}

PHOTO = photosynthetic rate $\mathrm{COND}=$ stomatic conductance $; \mathrm{FLUO}=$ chlorophyll fluorescence COLOR = leaf color deviation $; \mathrm{CLORO}=$ chlorophyll content; LAD = integrated leaf area (leaf area duration); TDW = total top dry weight; GRAIN = grain yield; ROOT = fresh weight of roots
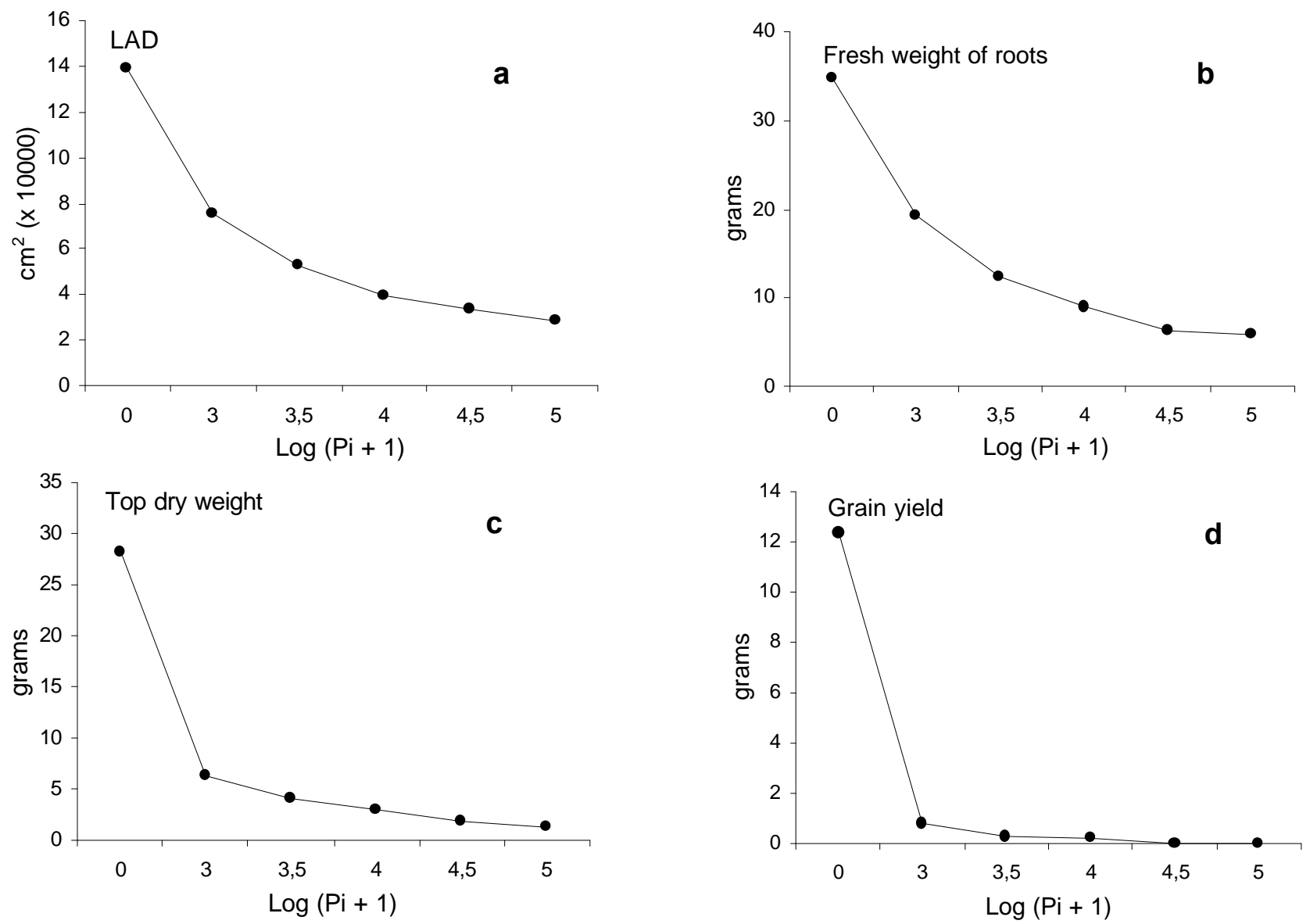

FIG. 2 - Integrated leaf area (leaf area duration = LAD) (a), fresh weight of roots (b), top dry weight (c), and grain yield (d) of susceptible 'Embrapa 133' soybean (Glycine max) inoculated with different population densities (Pi) of Heterodera glycines. 
primarily related to Pis (Barker \& Olthof, 1976), it is not uncommon for local variations in soil type, cultivars and climate to make the relationship Pi x damage erratic. Accordingly, a new concept for crop loss prediction models has recently been developed, particularly for leaf diseases. In these models, the photosynthesis and the area of healthy leaf, thought to be the most important parameters responsible for crop yield (Waggoner and Berger, 1987), are primarily taken into account. Hence, it can be suggested that the integrated leaf area (= LAD), which can be determined at any time during the crop cycle, could be used in damage prediction models for $H$. glycines-infected soybeans, after its validation under different soil and climatic conditions and cultivars.

Fresh root weight was clearly affected by increasing population levels (Figure 2b), confirming previously available data (Postuka et al., 1986). The dramatic reduction in total top dry weight and in grain yield values here observed even at the lowest Pis (Figures $2 \mathrm{c}$ and $2 \mathrm{~d}$ ) reinforce the view that $\mathrm{SCN}$ is a serious problem of soybean (Young, 1996). Actually, it is even possible that SCN population densities just above the detection level in soil may cause crop losses.

Contrary to what has been observed with many plantnematode interactions, in the association between $\mathrm{SCN}$ and the susceptible soybean cultivar Embrapa 133, damage was increasingly greater throughout the growth cycle and no sign of recovery could be detected over time in Experiments 1 and 2.

\section{ACKNOWLEDGEMENTS}

The authors thank Dr. Manoel Carlos Gonçalves for aiding with the statistical analysis and Dr. Gilberto José de Moraes for his suggestions and manuscript review.

\section{LITERATURE CITED}

BARKER, K.R. \& OLTHOF, T.H.A. Relationships between nematode population densities and crop responses. Annual Review of Phytopathology 14:327-353. 1976.

BIRD, A.F. Plant response to root-knot nematode. Annual Review of Phytopathology 12:69-85. 1974.

BRUN, W.A. Assimilation. In.: Norman, A.G. (Ed.) Soybean physiology, agronomy, and utilization. Londres. Academic Press. 1978. pp. 45-76.

DIAS, W.P., SILVA, J.F.V., WAIN, A.A. \& PEREIRA, J.E. Distribuição de raças de Heterodera glycines no Brasil. In: Silva, J.F.V. (Org.) O nematóide de cisto da soja: a experiência brasileira. Jaboticabal. Sociedade Brasileira de Nematologia. 1999. pp. 95-103.

HUNT, R. Plant growth analysis. London. Edward Arnold, 1978.

HUSSEY, R.S. \& WILLIAMSON, V.M. Physiological and molecular aspects of nematode parasitism. In: Barker, K.R., Pederson, G.A. \& Windham, G.L. (Eds.) Plant and nematode interactions. Madison, Wisconsin. American Society of Agronomy. 1998. pp. 87-108.

KAUSHAL, K.K. \& MADAVI, R. Effect of Heterodera avenae on the growth, photosynthesis and chlorophyll content in triticale. Indian Journal of Nematology 22:29-35. 1992.

KO, M.P., BARKER, K.R. \& HUANG, J.S. Nodulation of soybeans as affected by half-root infection with Heterodera glycines. Journal of Nematology 16:97-105. 1984.

KOENNING, S.R. \& BARKER, K.R. Soybean photosynthesis and yield as influenced by Heterodera glycines, soil type and irrigation. Journal of Nematology 27:51-62. 1995.

LOPES, D.B. Photosynthetic competence of bean leaves with rust and anthracnose. (Ph.D. Thesis). Gainesville. University of Florida. 1999.

LOVEYS, B.R. \& BIRD, A. The influence of nematodes on photosynthesis in tomato plants. Physiological Plant Pathology 3:525-529. 1973 .

MA, L.B., MORRISON, M.J. \& VOLDENG, H.D. Leaf greenness and photosynthetic rates in soybean. Crop Science 34:14111414. 1995.

McSORLEY, R. Population dynamics. In: Barker, K.R., Pederson, G.A. \& Windham, G.L. (Ed.) Plant and nematode interactions. Madison. American Society of Agronomy. 1998. pp. 109-133.

MELAKEBERHAN, H. Effects of nutrient source on the physiological mechanisms of Heterodera glycines and soybean genotypes interactions. Nematology 1:113-120. 1999.

MELAKEBERHAN, H., FERRIS, H. \& DIAS, J.M. Physiological response of resistant and susceptible Vitis vinifera to Meloidogyne incognita. Journal of Nematology 22:224-230. 1990.

MÜLLER, L. Fisiologia. In.: Miyasaka, S. \& Medina, J.C. (Eds.) A soja no Brasil. 1981. pp. 109-129.

NAGESH, M. \& DHAWAN, S.C. Effect of inoculum density of Heterodera avenae on photosynthetic efficiency, chlorophyll, and mineral contents of wheat. Indian Journal of Nematology 18:40-43. 1988.

POSTUKA, J.W., DROPKIN, V.H. \& NELSON, C.J. Photosynthesis, photorespiration, and respiration of soybean after infection with root nematodes. Photosynthetica 20:405410. 1986.

SCHANS, J. \& ARNTZEN, F.K. Photosynthesis, transpiration and plant growth characters of different potato cultivars at various densities of Globodera pallida. Netherland Journal of Plant Pathology 97:297-310. 1991.

SHIBLES, R., ANDERSON, J.C. \& GIBSON, A.H. Soybean. In.: Evans, L.T. (Ed.) Crop physiology. Some case histories. Cambridge. University Press. 1975. pp. 151-189.

WAGGONER, P.E. \& BERGER, R.D. Defoliation, disease and growth. Phytopathology 77:393-398. 1987.

WALLACE, H.R. The influence of root-knot nematode, Meloidogyne javanica, on photosynthesis and on nutrient demand by roots of tomato plants. Nematologica 20:27-33. 1974.

WRATHER, J.A., ANDERSON, T.R., ARSYAD, D.M., GAI, J., PORTO-PUGLIA, A., RAM, H.H. \& YORINORI, J.T. Soybean disease loss estimates for the top 10 soybean producing countries in 1994. Plant Disease 81:107-110. 1997.

YORINORI, J.T. Riscos de surgimento de novas doenças na cultura da soja. Anais, 1ํㅡㄹ Congresso de Tecnologia e Competitividade da Soja no Mercado Global, Cuiabá, MT. 2000. pp. 165-169

YOUNG, L.D. Yield loss in soybean caused by Heterodera glycines. Journal of Nematology 28:604-607. 1996. 